\title{
Comparison the Effect of Zinc Oxide and Magnesium Oxide Nano Particles on Long Term Memory in Adult Male Mice
}

\author{
Mahnaz Kesmati, ${ }^{1}$ Zeinab Sargholi Notarki, ${ }^{1}$ Narges Issapareh,, and Mozhgan Torabi ${ }^{1,}$ \\ ${ }^{1}$ Department of Biology, Faculty of Science, Shahid Chamran University, Ahvaz, IR Iran \\ "Corresponding author: Mozhgan Torabi, Department of Biology, Faculty of Science, Shahid Chamran University, Ahvaz, IR Iran. Tel: +98-9163217083, E-mail: \\ mozhgan.torabii@yahoo.com
}

Received 2015 July 08; Revised 2015 August 05; Accepted 2016 August 07.

\begin{abstract}
Background: Magnesium (Mg) and zinc (Zn) are two essential elemnts for normal performance of central nervous system. So that the learning and memory are influenced by these ions that antagonized NMDA (N methyl-D-aspartate) receptor.

Objectives: This study was conducted to evaluate the effect of nanoparticles of zinc oxide ( $\mathrm{ZnO}$ ) and magnesium oxide (MgO) on passive avoidance memory in mice.

Methods: In this experimental study adult male NMRI mice weighing $25 \pm 3 \mathrm{~g}$ were used. ZnO and MgO nano particles (1, 2.5 and 5 $\mathrm{mg} / \mathrm{kg}$, intrapretoneally (i.p.) were injected pre-training in model of passive avoidance learning. Memory was evaluated at 1,3 and 7 days after training. Delay time in coming down from the safe platform in step down apparatus was evaluated as an index of memory. Open field test was used for evaluation the locomotor activity.

Results: Nano MgO 2.5 and $5 \mathrm{mg} / \mathrm{kg}$ increased delay time in coming down from plateform at one day after training $(\mathrm{P}<0.05)$ in dose dependent manner. Nano ZnO 2.5 and $5 \mathrm{mg} / \mathrm{kg}$ reduced delay time in coming down from the platform 1, 3 and 7 day after training $(\mathrm{P}<0.05)$ and just 3 days after training $(\mathrm{P}<0.05)$ respectivley. Locomotor activity did not change in presence of $\mathrm{MgO}$ and/or $\mathrm{ZnO}$ nano particles.

Conclusions: It seems that various effects of nano $\mathrm{ZnO}$ and $\mathrm{MgO}$ on long term memeory is related to the different effects of $\mathrm{Zn}$ and $\mathrm{Mg}$ ions on receptors (such as NMDA) involved in memory process. Toxicity and/ or preservation of nanoparticle in body are another possible reasons.
\end{abstract}

Keywords: Magnesium Oxide, Zinc Oxide, Nanoparticles, Memory

\section{Background}

Learning and memeory are corrolated process that during of them different data stored in brain and recalled when requered [1]. Multiple factors can affect on memory and learning that the role of ions like magnesium and zinc can be significant $[2,3]$. Magnesium is the forht major cation in body and the secound major intracellular cation after potassium [4]. Magnesium ion deficiency has important effect on memory loss in people with Alzheimer's disease and increasing magnesium intake led to increase of memory in young mice and decrease of memory loss in old mice $[4,5]$. Zinc is a necessary elemnt for brain and other body organs physiological function [6]. Zinc ions play important role in behaviors associated with memory, learning and processes associated with brain aging so that the deficiency of zinc ion in diet can lead to loss of memory in animal models $[7,8]$.

On the other hands both of these elements have effects on common receptors like NMDA glutamatergic receptor that has impotrant role on memory processes and long term potentiation (LTP) $[9,10]$.

According to the above studies, suggests that the role of these elemnts in some cases such as learning and long term memory can be examined and compared.

It is notable that elements like zinc can influence blood-brain-brarier (BBB) permeability, while magnesium has a little ability in crossing of $\mathrm{BBB}[2,11]$. Intravenous injection of magnesium lead to little increase in cerebrospinal fluid magnesium [4].

There fore peripheral useage of these elements, because of the restrictions in crossing or disruption of BBB, is fundamental point for the treatment of zinc and magnesium deficiency in central nervous system.

By development of nano medicine, usage of metals oxide nanoparticles in some models of animal behavior growth up quickly [12-20]. Application of these nanoparticles, because of their special properties, could reduce some limitations of conventional drugs like restriction to crossing of blood-brain-barrier [15]. 
Our previous studies have shown that nanoparticles of metals oxide such as $\mathrm{ZnO}$ and $\mathrm{MgO}$ can influence some of behavioural responses [16-20]. Acute and chronic usage of nano $\mathrm{ZnO}$ has anxiolytic and antinociception effects in male and female rats $[12,13,15,16]$. Nano MgO reduced pain conception in mice and has anxiolytic effects in rats $[17,18]$. We have shown that post-training injection of nano $\mathrm{MgO}$ can improve the passive avoidance memory in adult male mice while post-training injection of nano $\mathrm{ZnO}$ can cause memory loss in adult male rats $[19,20]$.

\section{Objectives}

Since the effect of the nano $\mathrm{ZnO}$ and $\mathrm{MgO}$ in pretraining administration on long term memory has not been studied complately, the aim of this study is comparison between pre-training injection of $\mathrm{ZnO}$ and $\mathrm{MgO}$ nano particles, on long term memory in animal model of passive avoidance learning.

\section{Methods}

\subsection{Animals}

In this experimental study were used adult male NMRI mice weighting $25 \pm 3 \mathrm{~g}$. Animals purchased from the animal house of the medical science department of the joundi shapor university (Ahvaz, Iran) and were kept in plexiglass cages in room with 12/12 hours dark/light cycle and a temperature of $23 \pm 2{ }^{\circ} \mathrm{C}$ with adequate access to food and water. Animals were divided in to groups: control group (receiving saline \%0.9), groups receiving nano Zno and/or nano $\mathrm{MgO}$ in doses of 1, 2.5 and $5 \mathrm{mg} / \mathrm{kg}$ (i.p.).

Nano particles of MgO (Lolitech Co; Germany particle size $<50 \mathrm{~nm}$ ) and nano $\mathrm{ZnO}$ (Lolitech Co; Germany particle size $<70 \mathrm{~nm}$ ) dispersed in saline \%0.9, by ultrasonic bath (S2600 Co; Iran) for 15 minutes. Memory was evaluated by step- down apparatus (ST-5500 Co; Iran) as a passive avoidance learning model, 30 minutes after IP injection of drugs. Number of animals in each group were $7(\mathrm{~N}=7)$.

\subsection{Step-Down Apparatus}

This device is a box with three dimensions $(40 \times 30 \times$ $30 \mathrm{~cm}$ ). Three of plexiglass walls have dark colour and front wall made from transparent plexiglass that in it animal behavoir is visible. Graid floor of box is made of stainless steel and wooden platform $(2.5 \times 7 \times 27 \mathrm{~cm})$ (as a safe platform) set in the center of the graid floor. In training time mouse was placed on wooden platform and the step- down latency (SDL) was recorded. When the mouse stepped down and placed all its paws on the grid floor, received electrical shock (15 volt) for 15 seconds. SDL was defined as the time taken by the mouse to step down from wooden platform with its entire paw to grid floor. Immediately after shock animal is removed from the box and one day after training, the test stage was performed on trained mice. In this stage mice was placed again on wooden platforms in the box and step down latency recorded. The maximum time of stay on a wooden platform in this stage was 300 seconds. Three and seven days after training , like the first day of test, step down latency recorded again for investigation of long term memory in mice [21].

\subsection{Open Field Test}

Open field test is used for investigatin the effect of drugs on locomotor activity of animals different tests. Open filed apparatus is a plexiglass box $(30 \times 30 \times 30 \mathrm{~cm}$ Co; Iran) that placed on the wooden plateform that with 4 cross lines divided into nine parts. If the animal head's and two front limbs crossed from one of these lines considered one number for animal. The number of crossed lines during a certain period of time appearance as animal locomotor activity. When performing test, for animals adaption with the open field environment each mouse placed for 10 minutes in the ccenter of apparatus freely, and then locomotor activity recorded during 5 minutes The number of crossing lines during 5 minutes with animal head's and two front limbs was evaluated as the locomotor activity index.

\subsection{Statistical Analysis}

Data analyzed with Instat 3 software and all results were expressed as the mean \pm SEM. ANOVA was used for multiple comparisons between groups and post hock Tukey test was performed. Differences with a P value of $<$ 0.05 between experimental groups at each point were considered statistically significant.

In the present study, all procedures methods were carried out in accordance with institutional guidelines for animal care and use of laboratory animals, and approved by the department of biology of the Shahid Chamran University (Ahvaz, Iran)

\section{Results}

4.1. Effect of Pre-Training Injection of Nano $\mathrm{MgO}(1,2.5,5 \mathrm{mg} / \mathrm{kg})$ on Passive Avoidance Memory and Locomotor Activity

Figure $1 \mathrm{~A}$ showes that in nano $\mathrm{MgO}$ receiving groups $(2.5,5 \mathrm{mg} / \mathrm{kg})$, one day after training there was significant difference on step down latency level (SDL) in compared with control group $(0 \mathrm{mg} / \mathrm{kg})\left({ }^{*} \mathrm{P}<0.05\right)$. Nano MgO (5 mgkg) has tendency to increase memory at 3 and 7 days after traning but it was not significant. 
Also Figure $1 \mathrm{~B}$ shows that there were no significant difference in locomotor activity between all groups.

\subsection{Effect of Pre-Training Injection of Nano $\mathrm{ZnO}(1,2.5,5 \mathrm{mg} / \mathrm{kg})$ on Passive Avoidance Memory and Locomotor Activity}

Results on Figure 2A showes that nano ZnO $2.5 \mathrm{mg} / \mathrm{kg}$ significantly reduced memory at 1,3 and $7\left({ }^{*} \mathrm{P}<0.05\right)$ days after training with decrement of step down latency (SDL). Also nano $\mathrm{ZnO} 5 \mathrm{mg} / \mathrm{kg}$ has tendency to reduce memory one day after training and significantly reduced memory three days after training ( $\left.{ }^{*} \mathrm{P}<0.05\right)$. Figure $2 \mathrm{~B}$ also shows that nano $\mathrm{ZnO}$ in all days after training has no effect on locomotor activity of mice.

\section{Discussion}

In the present study it was shown that, pre-training injection of MgO nano particles could improve memory in dose dependent manner only one day after injection and these doses could not change locomotor activity in every days after training (Figure $1 \mathrm{~A}$ and $\mathrm{B}$ ).

On the other hands nano $\mathrm{ZnO} 2.5$ and $5 \mathrm{mg} / \mathrm{kg}$ (in a weaker level) significantly led to decrease of memeory in animals without any changes in locomotor activity of them (Figure $1 \mathrm{~A}$ and $1 \mathrm{~B}$ ).

Our previous studies have shown that post-training administration of nano MgO can improve memory in mice [19]. Also pre-training injection of nano ZnO can cause memory loss in rats [20].

NMDA receptor is a glutamate gated channel in central nervous system that has important role in learning, memory and in long-term potentiation (LTP) mechanism [22].

Synaptic plasticity of LTP is a ability that regulates synaptic transmition performance with regulation of the NMDA receptor numbers and some changes in it's subunits [23]. NMDA receptor is as the main target receptor in magnesium and zinc ions performance pathways [8-10, 2426].

Magnesium acts as a noncompetetive antagonist for NMDA receptors [10] and has a certain place in cation channel of NMDA receptor that blocked it in resting potential [4]. Increasing of magnesium in brain, enhancing block and down regulating of NMDA receptor [26, 27].

It is notable that this receptor inhibited with magnesium just in short time of cellular potentional, resting potentional, and with depolarization of post sinaptic cell this inhibitation can be removed quickly [4].

Increase of brain magnesium can lead to increas in selective expression of some subunits of NMDA receptor [22, 26] also induction of LTP in synaps of perforant - dentate gyrus pathway and synaps of Shaffer clusters in CA1 area is depend on NMDA glutamateric receptors [26-28]. In CA1 area, NMDA receptor has an important role in regulation of synaptic plasticity, learning and memeory process $[1,28]$. So magnesium can lead to increase of NMDA receptor activity, induction of LTP, increase of synaptic plasticity and improve of learning and memeory.

Up regulation in expression of NMDA receptor subunits is a homeostasis mechanism that not just returns activity of this receptor, that was reduced during resting potential, to initial level also causes more flow through this receptor and compensates it's activity reduction [4].

In this experiment nano MgO has a tendency to improve memory only 24 hours after training and the next days statistically is not significant. It seems that despite the small size of MgO nanoparticles and it's easier crossing through blood-brain-barier [14]. Acute administration of $\mathrm{MgO}$ nanoparticle has limited its improving effects and must be administered chronicaly for better function. Also toxical effects of nano $\mathrm{MgO}$ are as another inhibiting factors that prevent the reinforcing effects of it [29] that finding of these possible effects need to more studies.

On the other hands zinc ion affects NMDA receptor by two ways: noncompetetive voltage-dependent inhibition (allosteric) that reduces the frequency of channel valves opening and voltage-dependent inhibition that closes open channel by zinc ion [24].

Zinc inhibits NMDA receptor with high tendency at the 5-80 nanomolar concentration, voltage dependent inhibition with low tendency at the 45 - 79 micromolar concentration and inhibits receptor in voltage-independent manner with average tendency at the 1.6 - 9.5 micromolar concentration [24].

Dispaite of the magnesium, that act as a NMDA blocker, zinc ion make a noncompetetive- volatge-independent inhibition that probably reduces the frequency of channel valves opening $[24,30]$.

It seems that pre-training injection of nano $\mathrm{ZnO}$ probably increase zinc ions in glutamatergic synapse pathways and occures excessive inhibition of NMDA receptors, that ultimately reduces the incidence of LTP and reduces memory. Make changes in BBB permeability by zinc ions is other possible way.

In this experiment nano MgO had no long effect on memory while the effect of nano ZnO was longer than MgO. It seems that despite the small size of nanoparticles and easier crossing through blood-brain-barier, preservation of these particles in body may be related to the difference between their small size and or their toxicity because nano ZnO has been considered as one of the most toxic nanoparticles [14, 29]. 


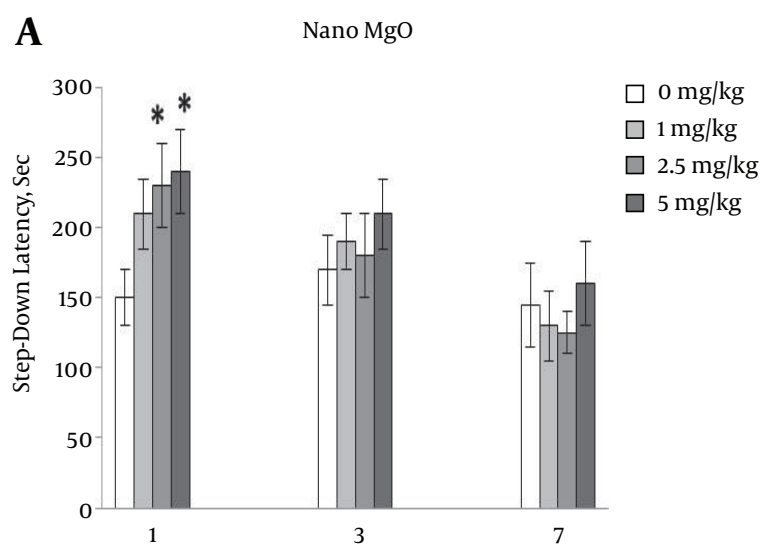

Days After Training

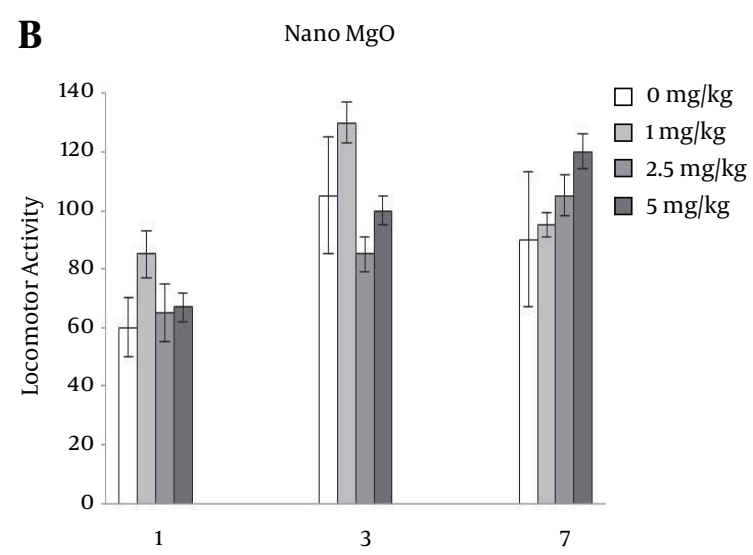

Days After Training

There were no significant difference between groups. In each column, ${ }^{*} \mathrm{P}<0.05$ in compared with control group $(0 \mathrm{mg} / \mathrm{kg})(\mathrm{N}=7)$.

Figure 2. Effect of Pre-Training Injection of Nano ZnO (1, 2.5, $5 \mathrm{mg} / \mathrm{kg})$ on A, Passive Avoidance Memory and B, Locomotor Activity During 1, 3 and 7 Days After Training
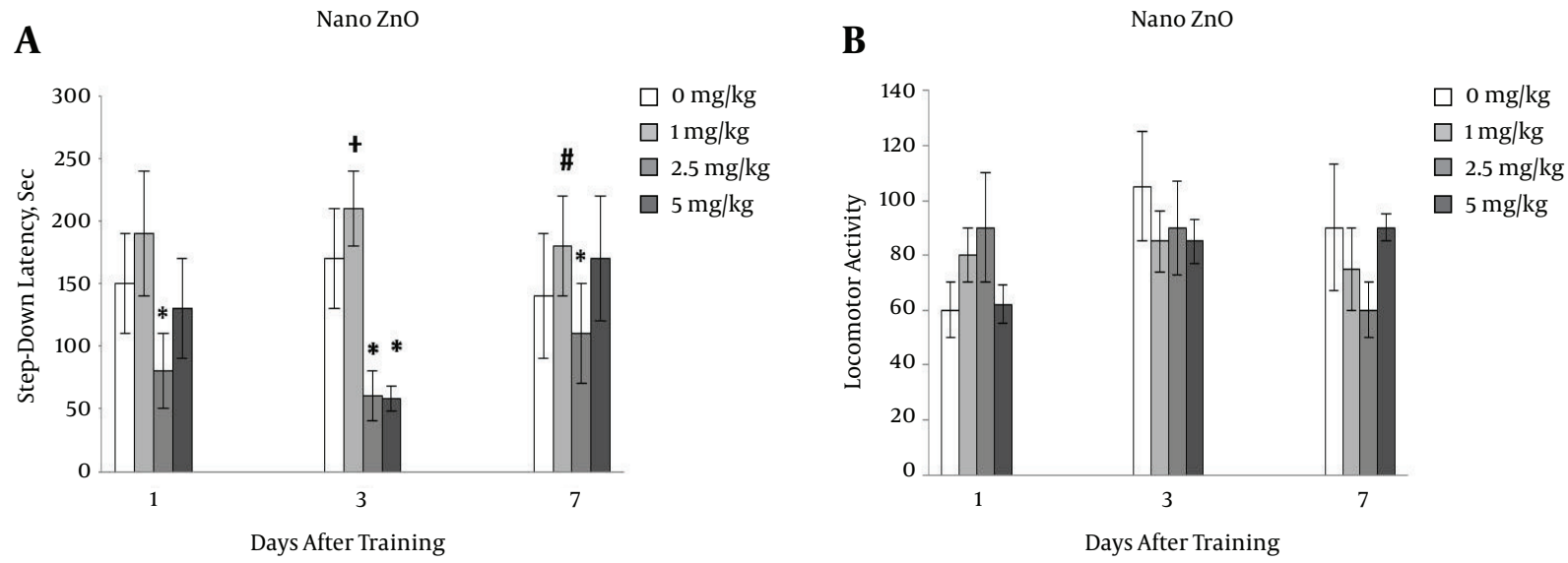

In each column, ${ }^{*} \mathrm{P}<0.05$ in compared with control group $(0 \mathrm{mg} / \mathrm{kg}),+\mathrm{P}<0.01 \mathrm{in}$ compared with groups receiving nano $\mathrm{ZnO} 2.5 \mathrm{mg} / \mathrm{kg}$ and $5 \mathrm{mg} / \mathrm{kg}$, \#P $<0.05 \mathrm{in}$ compared with group receiving nano $\mathrm{ZnO} 2.5 \mathrm{mg} / \mathrm{kg}(\mathrm{N}=7)$.

\subsection{Conclusion}

Our findings show that pre-training injection of magnesium and zinc released from $\mathrm{ZnO}$ and MgO nano particles have different effects on passive avoidance memory process and this despite the fact that both of $\mathrm{Zn}$ and $\mathrm{Mg}$ were introduced as NMDA receptor, an impotrant receptor in memory process, blocker. On the other hands the difference in time of their effects maybe related to various toxicity and preservation of these nanoparticles in body. Evaluation of these probably reasons and the others ways need to more investigation.

\section{Acknowledgments}

This study was supported by Shahid Chamran University of Ahvaz, Iran, grant number 92/302/18672. Hereby, researchers of this study would like to express their sincere gratitude to the esteemed vice-presidency for research of Shahid Chamran University for their financial and moral supports.

\section{Footnotes}

Authors Contribution: All authors had equal role in design, work, statistical analysis and manuscript writing. 
Funding/Support: Shahid Chamran University of Ahvaz, Iran.

Conflict of Interests: The authors declare no conflict of interest.

\section{References}

1. Michalak A, Kruk-slomka M, Biala G. The Molecular Basis of Memory: Mechanisms, Neurotransmitters and Receptors Involved in Cognitive Processes. Med Univ Lublin. 2011;24(3):197-207.

2. Vural H, Demirin H, Kara Y, Eren I, Delibas N. Alterations of plasma magnesium, copper, zinc, iron and selenium concentrations and some related erythrocyte antioxidant enzyme activities in patients with Alzheimer's disease. J Trace Elem Med Biol. 2010;24(3):169-73. doi: 10.1016/j.jtemb.2010.02.002. [PubMed: 20569929].

3. Hoane MR. Assessment of cognitive function following magnesium therapy in the traumatically injured brain. Magnes Res. 2007;20(4):229-36. [PubMed: 18271492].

4. Slutsky I, Abumaria N, Wu LJ, Huang C, Zhang L, Li B, et al. Enhancement of learning and memory by elevating brain magnesium. Neuron. 2010;65(2):165-77. doi: 10.1016/j.neuron.2009.12.026. [PubMed: 20152124].

5. Li W, Yu J, Liu Y, Huang X, Abumaria N, Zhu Y, et al. Elevation of brain magnesium prevents synaptic loss and reverses cognitive deficits in Alzheimer's disease mouse model. Mol Brain. 2014;7:65. doi: 10.1186/s13041-014-0065-y. [PubMed: 25213836].

6. Prasad AS. Discovery of human zinc deficiency: 50 years later. J Trace Elem Med Biol. 2012;26(2-3):66-9. doi: 10.1016/j.jtemb.2012.04.004. [PubMed: 22664333].

7. Suh SW, Won SJ, Hamby AM, Yoo BH, Fan Y, Sheline CT, et al. Decreased brain zinc availability reduces hippocampal neurogenesis in mice and rats. J Cereb Blood Flow Metab. 2009;29(9):1579-88. doi: 10.1038/jcbfm.2009.80. [PubMed: 19536073].

8. Takeda A, Tamano H. Insight into zinc signaling from dietary zinc deficiency. Brain Res Rev. 2009;62(1):33-44. doi: 10.1016/j.brainresrev.2009.09.003. [PubMed: 19747942].

9. Amico-Ruvio SA, Murthy SE, Smith TP, Popescu GK. Zinc effects on NMDA receptor gating kinetics. Biophys J. 2011;100(8):1910-8. doi: 10.1016/j.bpj.2011.02.042. [PubMed: 21504727].

10. Bekkers JM, Stevens CF. NMDA receptors at excitatory synapses in the hippocampus: test of a theory of magnesium block. Neurosci Lett. 1993;156(1-2):73-7. [PubMed: 8414193].

11. Yorulmaz H, Seker FB, Demir G, Yalcin IE, Oztas B. The effects of zinc treatment on the blood-brain barrier permeability and brain element levels during convulsions. Biol Trace Elem Res. 2013;151(2):256-62. doi: 10.1007/s12011-012-9546-y. [PubMed: 23179348].

12. Kesmati M, Torabi M, Teymuri Zamaneh H, Malekshahi Nia H. Interaction between anxiolytic effects of magnesium oxide nanoparticles and exercise in adult male rat. Nanomed J. 2014;1(5):324-30.

13. Kesmati M, Torabi M, Ghandizadeh-Dezfuli M. Nanoparticles of zinc oxide reduces acute somatic pain in adult female wistar rats. Zahedan J Res Med Sci. 2014;16(2):24-8.
14. Win-Shwe TT, Fujimaki H. Nanoparticles and neurotoxicity. Int $J$ Mol Sci. 2011;12(9):6267-80. doi: 10.3390/ijms12096267. [PubMed: 22016657].

15. Torabi M, Kesmati M, Harooni HE, Varzi HN. Different efficacy of nanoparticle and conventional zno in an animal model of anxiety. Neurophysiology. 2013;45(4):299-305.

16. Kesmati M, Torabi M. Interaction between Analgesic Effect of Nano and Conventional size of Zinc Oxide and Opioidergic System Activity in Animal Model of Acute Pain. Basic Clin Neurosci. 2014;5(1):80-7. [PubMed: 25436088].

17. Jahangiri L, Kesmati M, Najafzadeh H. Evaluation of analgesic and anti-inflammatory effect of nanoparticles of magnesium oxide in mice with and without ketamine. Eur Rev Med Pharmacol Sci. 2013;17(20):2706-10. [PubMed: 24174350].

18. Jahangiri L, Kesmati M, Najafzadeh H. Evaluation of Anticonvulsive Effect of Magnesium Oxide Nanoparticles in Comparison with Conventional MgO in Diabetic and Non-diabetic Male Mice. Basic Clin Neurosci. 2014;5(2):156-61. [PubMed: 25337374].

19. Abdolahzadeh Dashty M, Kesmati M, Khaje Por L, Najafzadeh Varzi H. The preventative role of MgO nanoparticles in amnesia induced by morphine in mouse. Iran Vet J. 2014;10(3):55-64.

20. Kesmati M, Vahdati A, Hoseini SE. The effects of acute administration of zinc oxidenanoparticles on long term memory in the presence and absence of vitamin C in adult male rat. Adv Environ Biol. 2014:260-7.

21. Narwal S, Saini DR, Kumari K, Narwal S, Singh G, Negi RS, et al. Behavior \& pharmacological animal models for the evaluation of learning \& memory condition. Indo Global J Pharm Sci. 2012;2(2):121-9.

22. VanDongen AM. Biology of the NMDA Receptor. CRC Press; 2008.

23. Talaei Zavareh SA, Hamidi G, Salami M. Long term potentiation as a mechanism for learning and memory. Yakhteh Med J. 2009;11(2):88105.

24. Rodriguez-Munoz M, de la Torre-Madrid E, Sanchez-Blazquez $\mathrm{P}$, Wang JB, Garzon J. NMDAR-nNOS generated zinc recruits PKCgamma to the HINT1-RGS17 complex bound to the $\mathrm{C}$ terminus of Mu-opioid receptors. Cell Signal. 2008;20(10):1855-64. doi: 10.1016/j.cellsig.2008.06.015. [PubMed: 18652891].

25. Liu G. Prevention of cognitive deficits in Alzheimer's mouse model by elevating brain magnesium. Mol Neur. 2012;7(1):1.

26. Chahal H, D'Souza SW, Barson AJ, Slater P. Modulation by magnesium of N-methyl-D-aspartate receptors in developing human brain. Arch Dis Child Fetal Neonatal Ed. 1998;78(2):F116-20. [PubMed: 9577281].

27. Reisinger C, Yelamanchili SV, Hinz B, Mitter D, Becher A, Bigalke $\mathrm{H}$, et al. The synaptophysin/synaptobrevin complex dissociates independently of neuroexocytosis. J Neurochem. 2004;90(1):1-8. doi: 10.1111/j.1471-4159.2004.02472.x. [PubMed: 15198661].

28. Hayashi Y, Nabeshima Y, Kobayashi K, Miyakawa T, Tanda K, Takao K, et al. Enhanced stability of hippocampal place representation caused by reduced magnesium block of NMDA receptors in the dentate gyrus. Mol Brain. 2014;7:44. doi: 10.1186/1756-6606-7-44. [PubMed: 24893573].

29. Arabnezhad Khanooki T, Fazilati M. The toxicity effect of magnesium oxide nanoparticles. Adv Environ Biol. 2014:969-74.

30. Chen L, Huang LY. Protein kinase C reduces Mg2+ block of NMDA-receptor channels as a mechanism of modulation. Nature. 1992;356(6369):521-3. doi:10.1038/356521a0. [PubMed: 1373227]. 